\title{
Gambaran Health Literacy, Pengetahuan, Kepercayaan, Sikap, Dan Perilaku Oleh Pemilik, Karyawan, Pengunjung Dalam Mencegah Covid-19 Di KMS Jember
}

\author{
Description of Health Literacy, Knowledge, Trust, Attitude, and Behavior of the Owner, Employees and \\ Visitors of KMS Jember \\ In Preventing COVID-19 at KMS Jember
}

\author{
Winarso $\mathrm{S}^{1}$, Irfiah ${ }^{2}$, Styantari $\mathrm{Y}^{3}$, Soraya $\mathrm{A}^{4}$, Andari $\mathrm{K}^{5}$, Wahyudi A $\mathrm{Z}^{6}$ \\ 1Universitas Jember, Jember \\ 2 Universitas Jember, Jember \\ 3 Universitas Jember, Jember \\ 4Universitas Jember, Jember \\ 5 Universitas Jember, Jember \\ Email: residensi4unej@gmail.com
}

\begin{abstract}
ABSTRAK. Corona Virus Disease 2019 yang disingkatkan dengan COVID-19 telah dinyatakan sebagai pandemi oleh WHO diakhir tahun 2020. Pandemi COVID-19 yang terjadi setiap sudut belahan negara di dunia dapat menunda atau sampai melumpuhkan semua aktivitas di berbagai masyarakat. Beberapa upaya langkah kebiasaan hidup baru yang dapat dilakukan untuk mencegah penyebaran COVID-19 di luar rumah harus yang di terapkan oleh seluruh jajaran masyarakat meliputi memakai masker, mencuci tangan dengan sabun atau handsanitizer, menjaga jarak 1 meter terutama di tempat umum seperti warung makan. Tujuan dari pelaksanaan residensi ini adalah untuk mengetahui gambaran healt literacy, pengetahuan, kepercayaan, sikap dan perilaku oleh pemilik, karyawan, pengunjung dalam mencegah COVID-19. Metode Pelaksanaan kegiatan ini menggunakan metode deskriptif dengan responden pemilik, 30 karyawan dan 30 pengunjung serta menggunakan instrumen berupa google form. Hasil pelaksanaan pada healthy literacy media yang digunakan oleh pemilik, karyawan dan pengujung ialah media elektronik, tetapi karyawan dan pengujung hanya sebagian yang mengikuti perkembagan COVID-19. Pada faktor pengetahuan dari pemilik sudah baik, dan terdapat kesenjangan antara pemilik dengan karyawan dan pengujung seperti pengetahuan gejala umum, dampak, cara penularan, dan orang beresiko tinggi tertular. Pada identifiaksi kepercayaan didaptkan bahwa pemilik percaya COVID-19 dan tidak percaya menular lewat udara sedangkan pada karyawan, dan pengunjung percaya akan COVID-19 dan percaya dapat menular lewat udara. Hasil identifikasi sikap dari karyawan dan pengujung sebagian baik dan lainnya kurang baik seperti bagaiamana keharusan menjaga jarak dan penggunaan masker yang benar, sedangkan pada pemilik sudah bersikap baik dan menyediakan semua kebutuhan protokol pencegahan COVID-19. Pada prilaku pemilik saat pandemi COVID-19 sudah bagus dengan mencontohkan penerapan protokol kesehatan dalam sebuah aturan standar operasional prosedur, sedangkan prilaku karyawan sebagain besar baik dengan tetap menerapkan protokol pencegahan COVID-19, sementara prilaku pengujung sudah baik, tetapi pada beberapa hal masih terkadang dilakukan seperti menyentuh mata, hidung, dan bagian wajh lainnya. Kesimpulan dari pelaksanan ialah beragamnya jawaban dari responden baik pemilik, karyawan dan pengunjung terkait pertanyaan antara pegetahuan, Health Literacy, kepercayaan, sikap, dan perilaku.
\end{abstract}

Kata Kunci: COVID-19, KMS, Pemilik, Karyawan, Pengunjung

ABSTRACT. Corona Virus Disease 2019 or COVID-19 was announced as pandemic by WHO by the end of 2020. The pandemic, a breakout around the globe, can slow down or paralyze all activities in every level of society. Several efforts have been done to avoid COVID 19 breakout including mask wearing, hand washing, sanitizing, or 1 meter social distancing between people in public places such as restaurants. This residency is aimed at identifying and describing the health literacy, knowledge, trust, attitude and behavior of the restaurant owner, employee and visitors to prevent COVID-19. This research applied descriptive method with respondents including the owner, 30 employees and 30 visitors using Google form as the instruments. The results reveals that healthy literacy media used by the owner, employees and visitors are electronic media and only small numbers of them were following the development of COVID 19 case. Owner's knowledge is good but there is gap between owner, employees and visitors in terms of knowledge on general symptoms, effects and contagious transmission of the disease as well as highly risk infected 
people. The trust identification shows that the owner believes COVID 19 does not airborne but the employees and visitors do. Meanwhile, attitude and behavior identification shows good and fair indicators for the employees and visitors in terms of social distancing and well-worn mask. Owner's attitude is considered good in terms of providing all protocol necessity to prevent COVID19. Owner's behavior during the COVID-19 pandemic are considered good by initiating health protocols by applying the standardized operational procedures. Furthermore, the behavior of employees are mostly good in terms of health protocol application to prevent COVID-19. On the other hand, visitors are basically good but several of them still touched their eyes, nose and other parts of their face. In conclusion, the various answers from respondents (owners, employees and visitors) are varied in terms of their knowledge, health literacy, trust, attitude and behavior.

Keywords: COVID-19, KMS, owner, employee, visitors

\section{Pendahuluan}

Corona Virus Disease 2019 (COVID-19) telah dinyatakan oleh WHO menjadi pandemi. Penyebaran hingga saat ini sudah semakin meluas dengan diiringi pertambahan jumlah kasus positif dan kasus kematian. Indonesia merupakan negara yang sedang berjuang melawan pandemi COVID-19 Terhitung data sebaran sampai akhir Oktober 2020 kasus terknfirmasi positif sebanyak 410.088 jiwa, dinyatakan sembuh sebanyak 337.801 jiwa serta dinyatakan meninggal sebanyak 13.869 jiwa [15].

Proses percepatan penanganan COVID-19 di Indonesia diperlukan strategi dan upaya yang komprehensif karena perkembangan kasus COVID-19 di Indonesia semakin meluas di semua sektor bidang. Langkah yang diambil oleh pemerintah Indonesia melalui surat keputusan Presiden Nomor 11 Tahun 2020 tentang penanganan COVID-19 Pemerintah Indonesia telah menetapkan Kedaruratan Kesehatan Masyarakat COVID-19 [11]. Kebijakan lain juga diikuti dengan keputusan Presiden Nomor 12 Tahun 2020 tentang Penetapan Bencana Nonalam terkait kasus pandemi COVID-19 [12].

Seiring kebijakan yang ditetapkan oleh pemerintah Indonesia dalam hal pencegahan penyabaran COVID-19 harus diikuti secara disiplin oleh semua pihak karena peran serta dari pemrintah dari tingkat pusat, tingkat provensi, kabupaten hingga tingga kecamatan dan desa harus bersinergi. Upaya penanggulangan pandemi COVID19 yang dilaksanakan oleh semua tingkat pemerintah sesuai instruksi presiden tersebut harus juga diikuti oleh pihak pihak swasta baik yang bergerak dalam perdaganga, perusahan atau sektor pariwisata dan juga sektor pendidikan.

Aturan yang ditetapkan oleh Pemerintah Indonesia menerapkan physical distancing, social distancing, pengadaan alat pelindung diri (APD) seperti masker, alat cuci tangan dan sanitisi yang mememnuhi, sampai pada pembatasan sosial berskala besar (PSBB) sebagai bentuk langkah yang komprehensif dalam upaya preventif penyebaran COVID-19. Penetapan aturan penanggulangan bencana COVID-19 juga diterapkan oleh pemerintah kabupten Jember yangjuga sudah menjadi basis daerah dengan zona merah dengan peningkatan jumlah kejadian positif COVID-19 seperti gambar berikut.

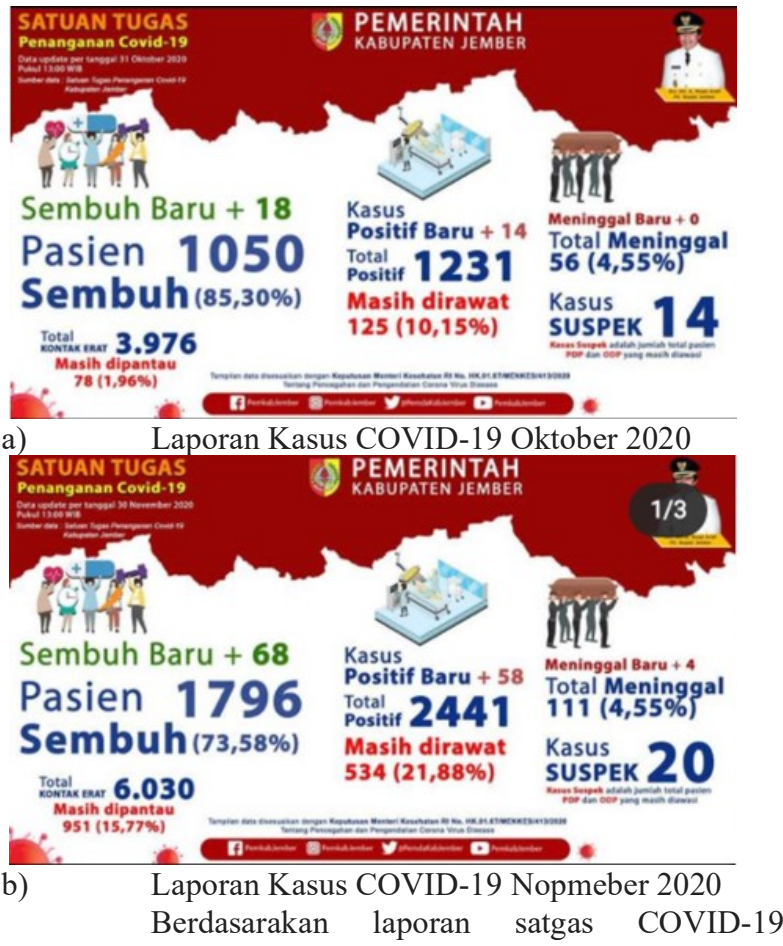

pemerintah kabupaten jember sesuai gambar point $a$ dan $b$ dinyatakan akhir Oktober 1.231 orang dan akhir Nopember 2.441 orang [9]. Jumlah kasus kematian COVID-19 pada bulan oktober 56 sejumlah jiwa dan akhir Nopember 111 jiwa [9]. Meningkatnya jumlah kasus dan diterapkannya aturan pencegahan dan penularan COVID-19 harus diikuti oleh semua aspek lapisan masyarakat tidak terkecuali dunia usaha.

Besarnya jumlah populasi pekerja serta mobilitas dan interaksi penduduk membuat dunia usaha dan masyakat pekerja memiliki kontribusi yang besar dalam memutus mata rantai penularan COVID-19. Penyeusuaian di tempat kerja seperti rumah makan atau warung merupakan salah satu fokus mobilisasi interaksi dan berkumpulnya orang berpeluang besar dalam penularan COVID-19 harus dilakukan pencegahan secara dini. Warung KMS yang menjadi salah satu warung makan favorit bagi kalangan masyarakat dengan jumlah konsumen kurang lebih 300 orang dan 60 karyawan setiap harinya harus secra dini melakukan pencegahan COVID-19. Berdasarkan uraian terkait kasus kejadian COVID-19, aturan pencegahan dan penularan COVID-19 dapat dilakukan identifikasi pelakasanaan pencegahan penularan dan penyebaran COVID-19 di Warung KMS Jember. 


\section{Bahan dan Metode}

Pelaksanaan kegiatan menerapkan analisis deskriptif kuantitatif dengan nara sumber atau responden terdiri dari pemilik, 30 karyawan, dan 30 pengunjung. Instumen pengumpulan data menggunakan google form dengan pilihan multiple choice.

Waktu dan Tempat

Pelaksanaan kegiatan residensi dilaksanakan pada tanggal 17-18 Oktober 2020 di Warung Kober Mie Setan yang terletak di jalan Karimata, Gumuk Kerang, Sumbersari, Kec. Sumbersari, Jember - 68121.

Bahan dan Alat

Bahan dan alat dalam pelaksanaan residensi ini menggunakan kuesioner online yang berupa Google Form untuk mengukur semua variabel yang disebarkan kepada responden yang kemudian hasilnya berupa kategori.

\section{Prosedur Pelaksanaan}

a. Peneliti menjelaskan kepada pemilik, karyawan dan pengunjung Kober Mie Setan tentang prosedur atau tata cara pengerjaan soal sebelum link soal google form dibagikan.

b. Pemilik, karyawan dan pengunjung Kober Mie Setan yang telah mendapatkan penjelasan dan mengerti tentang tata cara dalam pengerjakan soal, maka dilanjutkan dengan membagikan link google form kepadan 61 repsonden dengan instrumen yang berisi beberapa pertanyaan

c. Semua responden menjawab pertanyaan sesuai dengan link google form untuk pemilik, karyawan, dan pengujung yang berbeda

d. Pengisian jawaban oleh repsonden menggunakan handpond android masing - masing dan didampingi oleh pelaksana

e. Hasil jawaban soal yang sudah di isi oleh seluruh responden kemudian tersimpan di google form, dilakukan pengolahan data secara analisis deksriptif.

\section{Hasil dan Pembahasan}

Healt Literacy pemilik, karyawan, dan pengunjung dalam mencegah COVID-19 di Kober Mie Setan Kabupaten Jember

Pemilik

Pemilik merasa mudah dalam mengakses informasi terkait protokol era new normal COVID-19 dengan menggunakan media elektronik khusus nya melalui jurnal penelitian dan merupakan media yang tepat dan sesuai dalam mencari informasi dan membandingkan informasi yang di dapatkan dari media lain. Menurut pemilik, informasi terkait bahaya tidak mematuhi protokol kesehatan di era new normal dari masayarakat belum akurat hal ini dapat disebabkan karena banyak beredarnya berita hoax di masyarakat tentang COVID-19 dan protokol kesehatan di era new normal sehingga meresahkan masyarakat terkait beredarnya isu palsu atau berita bohong tentang COVID-19, terlebih lagi masyarakat belum dapat menentukan dengan baik bahwa berita yang beredar tersebut adalah berita bohong [4].

Kondisi pandemi COVID-19 yang datang dan meluas dengan singkat keseluruh dunia dan belum adanya vaksin membuat sebagian besar di masyarakat memiliki tingkat kecemasan yang tinggi atau bisa sampai takut. Kecemasan dan ketakutan diperburuk dengan rendahnya Health Literacy sehingga narasi yang beredar tentang konspriasi oleh negara maju yang beredar di media informasi elektornik sangat mudah dipercaya. Upaya penjernihan narasi berita di era post-truth saat ini sangat sulit dilkukan, sebab narasi di media sosial membagikan informasi bias dan memancing emosi publik secar bersamaan hingga menyababkan pemikiran makar. Berdasarkan tingginya kejadian narasi hoax tentang COVID-19 menuntut pengguna layanan media maya atau pengguna internet untuk memiliki pemikiran yang kritis, selektif, dan analitis dalam hal menerima dan atau mebagikan narasi berita COVID-19 di media massa [8].

Kondisi narasi hoax tentang COVID-19 yang beredar luas tanpa adanya kontrol secara rutin oleh pemerintah sangat mendukung gaduhnya masyarakat ditengah pandemi. Pemilik menyatakan dinas terkait di daerah Jember harus lebih rutin dalam melakukan sosialisasi COVID-19 baik dari segi informasi perkembangan dan pencegahan. Upaya yang dilakukan oleh pihak kedinasan terkait dalam praktinya terdapat upaya pemerintah dalam mensosialisasikan mengenai COVID-19 dengan penerapan strategi bagi masyarakat dengan penjelasan pandemi COVID-19 yang mewabah dengan cara memberikan penjelasan menggunkan bahasa daerah terakit.

Usah lain dari program pengaggulangan pencegahan COVID-19 dengan menerbitkan situs resmi covid.go.id yang tujuannya masyarakat dapat mengakses informasi satu pintu sehingga dapat meminimalisir narasi hoax yang beredar dan masyarakt dapat memahami dengan lebih jelas, jernih, benar, dan tepat tentang COVID-19[5]. Dampak positif lain dari situs resmi tersebut masyarakt mendapatkan edukasi terkait langkah - langkah pencegahan COVID-19 dalam aktivitas kesehariannya [5].

\section{Karyawan}

Bagi karyawan sebagian besar telah melakukan health literacy terhadap protokol kesehatan era new normal pandemi COVID-19. Jumlah karyawan sebanyak 12 karyawan atau 40\% melakukan akses informasi terhadap protokol kesehatan era new normal pandemi COVID-19. Karyawa yang sebagian besar merasa mudah mendapatkan informasi yang benar dan tepat terkait protokol kesehatan di era new normal baik melalui media elektronik. Media yang banyak di gunakan adalah platform instagram, kemudian karyawan juga merasa media yang mereka gunakan untuk mengakses informasi tentang COVID-19 sudah sesuai.

Pertanyaan paling banyak yang mendapatkan jawaban tidak dari yaitu pada pertanyaan tentang:

Membandingkan 1 sumber informasi satu dengan sumber informasi yang lain 
Memastikan informasi yang anda dapatkan dari orang terdekat (keluarga), tetangga atau masyarakat dengan media

Antusias ketika membahas informasi terkait bahaya tidak mematuhi protokol kesehatan

Karyawan menerima narasi COVID-19 dari media paltform belum melakukan perbandingan terhadap informasi secara maksimal dapat menjadi salah satu penyebab karyawan mempercayai hoax atau narisi bohong yang beredar, karena dengan melakukan perbandingan informasi maka akan menghindari dari terkena berita bohong. Selain itu karyawan yang tidak memastikan berita yang di dapatkan dari keluarga atau masyarakat dapat memicu missinformasi dan mempercayai naris berita tentang COVID-19 dengan sumber belum terpercaya. Terdapat beberapa karyawan yang kurang antusias dalam membahas tentang informasi COVID-19 hal ini dapat menjadi penyebab beberapa karyawan masih belum mengindahkan protokol COVID-19 seperti pada karyawan bagian kasir yang masih belum menggunakan hand sanitizer setelah menyentuh uang, serta beberapa karyawan masih tidak menjaga jarak dengan karyawa lainnya.

\section{Pengunjung}

Hasil identifiaksi pelaksanaan yaitu sejumlah 22 orang pengunjung melakukan health literacy terhadap langkah pencegahan COVID-19 atau protokol kesehatan pada masa pandemi COVID-19. Perbandingannya sejumlah 8 pengunjung belum melaksanakan akses informasi secar tepat terhadap bagaimana langkah pencegahan COVID-19 di masa new normal atau yang sering disebut protokol kesehatan pecegan COVID-19.

Berdasarakan hasil jawaban responden tersebut didaptkan bahwa $73 \%$ pengunjung sudah mudah dalam hal mendapatkan informasi terkait COVID-19 dan bagaimana langkah menerapkan protokol kesehatan sebagai langkah pencegahan COVID-19. Narasi informais yang diperoleh dan dibagikan baik melalui media elektronik yang banyak digunakan adalah platform Instagram dan Youtube, kemudian pengunjung juga merasa media yang mereka gunakan untuk mengakses informasi tentang COVID-19 sudah sesuai.

Jawaban tidak dari pengunjung terdapat pada pertanyaan mengenai keakuratan informasi terkait bahaya ketidakpatuhan penerapan protokol pencegahan COVID-19 oleh masyarakat di tempat publik. Pengunjung merasa bahwa informasi yang beredar di masyarakat belum akurat, hal ini di dukung oleh banyaknya narasi hoax yang beredar di masyarakat melalui media elektronik.

Pernyataan pengunjung terkait belum akuratnya informasi yang diterima sejalan dengan health literacy yang disampaikan oleh pengunjung terkait membandingkan informasi yang di dapatkan dari sumber satu dengan sumber lainnya. Health Literacy yang dilakukan oleh pengunjung sudah baik, akan tetapi terdapat beberapa hal yang ditemukan di lapangan bahwa pengunjung masih belum mengindahkan protokol pencegahan COVID-19 seperti menjaga jarak, pengunjung masih tidak menggunakan masker dengan tepat dan pada saat antri pengunjung masih belum menjaga jarak meskipun sudah ada himbauan jaga jarak yang di tempel di Kober Mie Setan.

Pengetahuan pemilik, karyawan, dan pengunjung dalam mencegah COVID-19 di Kober Mie Setan Kabupaten Jember

Adanya kesenjangan pengetahuan terkait COVID-19 antara pemilik, karyawan dan pengunjung, didapatkan bahwa pengetahuan pemilik terhadap COVID-19 bagus, sedangkan karyawan ada beberapa pengetahuannya masih kurang terkait antara lain:

Gejala umum dari COVID-19 adalah demam $\geq 38$ derajat celcius, batuk kering, susah nafas

Dampak COVID-19 cukup berbahaya karena dapat menular dengan cepat dan berkisar satu dari lima orang dapst menderita sakit lebih parah seperti pneumonia dengan gejala yang bertahap dan berkelanjutan

COVID-19 bisa menular lewat udara

Orang yang berisiko tinggi adalah orang dengan usia $>60$ tahun atau usia lanjut, dan orang dengan kondisi secara medis sudah teradapat penyakit penyerta seperti diabetes, hipertenis dan penyakit jantung koroner, bronkitis kronis pada paru-paru.

Untuk pengunjung ada beberapa pengetahuan yang masih kurang dan belum diketahui antara lain:

Orang yang berisiko tinggi adalah orang dengan usia $>60$ tahun atau usia lanjut, dan orang dengan kondisi secara medis sudah teradapat penyakit penyerta seperti diabetes, hipertenis dan penyakit jantung koroner, bronkitis kronis pada paru-paru

Dampak COVID-19 cukup berbahaya karena dapat menular dengan cepat dan berkisar satu dari lima orang dapst menderita sakit lebih parah seperti pneumonia dengan gejala yang bertahap dan berkelanjutan

COVID-19 bisa menular lewat udara

Orang bisa tertular COVID-19 melalui tetesan sedikit atau banyak cairan (droplet) yang keluar dari hidung dan mulut. Cairan yang disebut droplet tersebut biasanya muncrat atau keluar saat bersin, berbicara, dan batuk. Penularan droplet selanjutnya bisa dari berjabatan tangan dengan orang lain yang sebelumnya telah memegang bagian hidung atau mulut.

Kepercayaan pemilik, karyawan, dan pengunjung dalam mencegah COVID-19 di Kober Mie Setan Kabupaten Jember

Pemilik

Pemilik menjawab percaya terhadap penularan COVID-1 9 melalui cairan yang menempel di setiap alat makan. Bentuk pencegahan dengan mencuci tangan dan penyemprotan meja menggunakan disinfektan dapat mencegah COVID-19. Pemilik menjawab tidak percaya bahwa tertular COVID-19 merupakan takdir yang maha kuasa yang tidak diawali dengan usaha pencegahan dan berdoa sebelumnya. Menurut pemilik untuk mencegah penularan COVID-19 harus melakukan upaya pencegahan sesuai dan disiplin dengan protokol pencegahan yang 
ditetapkan. Hal tersebut didukung oleh pendidikan dan pengetahuan pemilik yang sudah luas.

Pemilik merupakan lulusan starata 2 jurusan ilmu kesehatan masyarakat, sehingga pemilik sangat mengetahui dan paham terhadap penularan COVID-19. Pemilik Kober Mie Setan di Jember telah melakukan beberapa upaya untuk mencegah terjadinya penularan COVID-19 di Kober Mie Setan seperti membuat himbauan dan menempelkan himbauan tentang pencegahan COVID-19 berupa himbauan menjaga jarak, himbauan mencuci tangan dengan benar, himbauan wajib menggunakan masker.

Karyawan

Sebagian besar karyawan menjawab percaya terhadap penularan COVID-19 melalui cairan yang menempel di alat makan, melalui udara tanpa sirkulasi, serta karyawan percaya bahwa pembatasan pengunjung dapat mengurangi resiko penularan COVID-19. Usaha lain untuk mencegah COVID-19 degan minum vit c, mencuci tangan dengan air mengalir dan sabun, serta penyemprotan semua sudut warung menggunakan disiinfektan terutama pada bagian meja dan kursi pengujung.

Hasil lain pada $93 \%$ karayawan juga percaya bahwa tertular COVID-19 merupakan takdir yang maha kuasa yang tidak diawali dengan usaha pencegahan. Penyampaian lain oleh karyawan juga percaya bahwa tubuh terpapar COVID-19 dapat sembuh dengan sendirinya, kurangnya tingkat kepercayaan karyawan juga disebabkan kurangnya akses informasi mereka terhadap keterbaruan informasi tentang COVID-19. Hal ini dapat menjadi penyebab beberapa karyawan masih belum mengindahkan protokol COVID19. Protokol pencegahan yang sering terlupakan seperti beberapa masih sering lupa menjaga jarak dengan karyawan lainnya. Didukung oleh hasil penelitian yang menyatakan bahwa kondisi percayanya dan tidak percayanya sebagain masyarakat dapat menghambat penerapan pencegahan COVID-19 [10].

Pengunjung

Hasil identifikasi bahwa pengunjung menyatakan percaya terhadap penularan COVID-19 melalui cairan yang menempel di alat makan, melalui udara tanpa sirkulasi, percaya bahwa pembatasan pengunjung dapat mengurangi resiko penularan COVID-19, minum vit c, mencuci tangan dan penyemprotan daerah tempat makan menggunakan disinfektan dapat mencegah COVID-19 terutama pada meja dan kursi pengujung. Hasil identifkasi bagian sebesar 25\% lain besar pengunjung juga percaya bahwa tertular COVID-19 merupakan takdir yang maha kuasa yang tidak diawali dengan usaha pencegahan serta $60 \%$ pengunjung juga percaya bahwa tubuh terpapar COVID-19 dapat sembuh dengan sendirinya.

Kondisi kepercayaan tersebut dikarenakan beberapa pengunjung masih memiliki pengetahuan yang rendah dan akses informasi yang juga kurang. Kejadian ini dapat menjadi penyebab beberapa pengunjung masih belum mengindahkan protokol COVID-19 seperti pengunjung masih abai menjaga jarak, pengunjung masih belum tepat menggunakan masker dan pada saat antri pengunjung masih lupa menjaga jarak meskipun sudah ada himbauan secara lisan dan tulisan.

Kondisi kurangnya disiplin melaksananakan pencegahan COVID-19 tersebut didukung dengan hasil penelitian yang menyatakan bahwa kepercayaan setiap Indvidu terhadap COVID-19 akan sangat mendukung pencegahan dalam aktivitas kesehariannya tidak terkecuali saat membeli konsumsi di warung makan, di Slovenia menyatakan bahwa kepercayaan berpengaruh terhadap kepatuhan pedoman pencegahan COVID-19 dengan nilai signifikansi P 0,001 yang diterapkan di negaranya[10].

Sikap pemilik, karyawan, dan pengunjung dalam mencegah COVID-19 di Kober Mie Setan Kabupaten Jember

Pemilik setuju terhadap semua item pertanyaan sehingga disimpulkan bahwa pemilik sudah mempunyai sikap yang baik dengan melakukan upaya pencegahan terhdap COVID-19.

Karyawan sudah memiliki sikap yang baik dalam melakukan upaya pencegahan COVID-19 akan tetapi masih ada beberapa karyawan yang belum mematuhi protokol pencegahan COVID-19 seperti masih tidak menggunakan masker dan masih tidak menjaga jarak antara karyawan satu dan karyawan lainnya. Akan tetapi masih banyak karyawan yang masih kurang peduli untuk mencari informasi tentang perkembangan penyakit COVID-19 seperti pertanyaan nomor 9, yaitu didapatkan bahwa hanya $36,8 \%$ karyawan yang masih antusias mengikuti perkembangan penyakit COVID-19 dengan tujuan untuk mencegah penularan virus.

besar pengunjung masih banyak yang belum menerapkan protokol kesehatan selama pandemi COVID-19. Seperti menggunakan masker, menerapkan cuci tangan 7 langkah dengan sabun atau hand sanitizer, menjaga jarak 1 meter dengan orang lain, jarang menerapkan etika batuk yang baik dan benar, dan ada beberapa dari mereka yang masih belum tahu tentang etika batuk.

Perilaku pemilik, karyawan, dan pengunjung dalam mencegah COVID-19 di Kober Mie Setan Kabupaten Jember

Perilaku baik dari setiap pribadi orang tentunya mendukung upaya pencegahan penularan COVID-19 yang semakin meluas [3]. Disiplinnya seseorang dalam menerapkan perilaku kesehatan dipengaruhi oleh banyak faktor diantaranya pengetahuan, persepsi, emosi, motivasi, dan lingkungan. Eksplorasi tentang perilaku kesehatan ditengah - tengan masyarakat saat pademi COVID-19 dapat dilihat dari berbagai komponen, diantaranya tentang kerentanan terpapar penyakit, hambatan dalam upaya pencegahan, manfaat dalam hal pencegahan, adanya dorongan atau dukungan, dan pemikiran setiap individu tentang kemampuan untuk melakukan upaya pencegahan [2].

Pemilik

Hasil pelaksanaan kegiatan ini menunjukkan bahwa pemilik warung makan berperilaku baik dalam mencegah penularan COVID-19. Bentuk perilaku dalam hal ini yaitu menyediakan alat yang tercantum dalam SOP protokol kesehatan warung makan seperti tempat mencuci tangan, 
sabun cuci tangan, air mengalirm, sarung tangan, masker, desinfektan, dan himabauan secara tertulis. Pemenuhan fasilitas tersebut tentunya sudah baik namun terdapat evaluasi pada jarak meja makan yang cukup rapat perlunya ditambhakan kaca pembatas meja antar pengunjung. Solusi yang diberikan yaitu memberikan edukasi kemudian bekerjasama dengan untuk pengadaan den pemasangan kaca pemabatas pengunjung.

\section{Karyawan}

Hasil pelaksanaan menunjukkna bahwa sebanyak $90 \%$ karyawan mempunyai perilaku yang baik. Bentuk perilaku yang ditunjukkan yaitu selalu menggunakan masker saat bekerja, sering mencuci tangan dengan sabun saat bekerja, menjaga jarak dengan pengunjung maupun dengan rekan kerja, selalu mengecek suhu pengunjung yang datanng ke warung mie kober dan memastikan meja makan, alat makan, dan lingkungan warung selalu bersih. Perilaku karyawan warung mie kober dalam mematuhi protokol kesehatan sudah baik hal ini dikarenakan pemahaman karyawan warung yang cukup baik dengan latar belakang mayoritas karyawan warung berpendidikan menengah atas. Sabanyak $10 \%$ karyawan atau 3 karyawan yang mempunyai perilaku yang tidak baik hal ini dapat ditunjukkan dengan menjawab kadang-kadand pada pernyataan menggunakan masker dan face shield sebelum masuk tempat kerja. Saat diwawancarai bahwa karyawan hanya tidak menggunakan face shield saja akan tetapi ketika masuk ke warung hanya menggunakan masker. Kejadian tersebut perlu dilakukan paya edukasi sebagai bentuk penyelesaian masalah. Upaya yang dilakukan oleh peneliti pada karyawan yaitu memberikan sosialisasi dalam bentuk edukasi tentang perilaku mencegah penularan COVID-19 dengan disiplin menggunakan masker dan face shield, mencucui tangan dengan air mengalir secar benar, dan menjaga jarak dengan harapan karyawan mampu berperilaku sesuai protokol kesehatan di warung saat bekerja dan minim resiko terpapar COVD-19.

\section{Pengunjung}

Hasil pelaksanaan menunjukkan sebanyak $80 \%$ pengunjung mempunyai perilaku yang baik. Upaya perilaku yang dilaksanakan terliha jelas antara lain disiplin dalam penggunaan masker secara tepat ketika berknjung di warung makan mie kober, mencuci tangan disertai sabun dan air mengalir atau dengan membawa hand sanitizer untuk digunakan secara probadi, berusaha menghindari atau menjauhi kerumunan dengan tetap menjaga jarak ketika mengantri menunnggu makanan dan mengantri saat membayar di kasir serta menjaga social ataupun physical distancing.

Hasil pengumpulan data sebanyak 20 orang atau $20 \%$ pengunjung yang perilaku kepatuhannya tidak baik. Perilaku ini dibuktikan dengan 3 pengunjung tersebut menjawab kadang - kadang pada pernyataan menghindari menyentuh hidung, mata, mulut saat di warung KMS. Hasil jawaban kadang - kadang pada pernyataan lain seperti menutup hidung dan mulut anda dengan tissue, kain, atau siku ketika bersin dan batuk sebanyak berjumlah lima pengunjung. Jawaban dengan kadang-kadang pada pernyataan mencuci tangan segera setelah batuk, bersin, atau menyentuh hidung sebanyak 4 pengunjung.

Pada pernyataan membungkus makanan yang dibeli untuk mengurangi terpapar COVID-19 dan pernyataan memesan makanan atau minuman yang dapat meningkatkan imunitas tubuh misal vitamin c sebanyak 2 pengunjung dengan jawaban terkadang. Pada saat makan dan minum anda melepas masker dan melipatnya dengan benar sebanyak 8 orang dan seluruh responden pengunjung (30 pengunjung) menjawab tidak pernah pada pernyataan memilih pembayaran non tunai untuk menghindari penularan Covid dan pernyataan memilih menggunakan alat makan yang dibawa secara pribadi pribadi.

Menurut Ta'adi et al. kepatuhan seseorng disiplin dalam menerapkan aturan yang ditetapkan, pengetahuan dapat menjadi faktor utama yang dapat berpengaruh. Berdasarkan luasnya pengetahuan seseorang tentang sesuatu hal termasuk pandemi COVID-19, maka orang tersebut akan bisa merencakan keputusan yang tepat bentuk pencegahannya [13]. Dapat ditaruk garis kesimpulan bahwa seseorang dengan kemampuan dan bisa mendapatkan informasi tentang COVID-19 yang jelas dan tepat, maka ia bisa merencankan dan melaksanakan program pencegahan COVID-19 tersebut secara maksimal.

Hasil lain dari kegiatan menunjukkan bahwa responden atau seserang dengan tingkat pendidikan lebih tinggi atau dalam hal ini menengah atas atau pendidikan tinggi akan menunjukkan lebih patuh dibandingkan dengan responden dengan pendidikan dibawahnya dalam hal ini dasar dan menengah pertama. Kondisi pendidikan tersebut akan sejalan dengan pembentukan perilaku seseorang akan berprilaku baik atau tidak. Berdasarkan hal tersebut pendidikan memiliki peranan penitng dalam menentukan keinginan tahu sesorang untuk berbuat prilaku lebih baik. Artinya dapat ditarik garis kesimpulan bahwa tingkat pendidikan menjadi latar belakang yang mendukung pengetahuan seseorang untuk selanjutnya meningkatkan kedisiplinan berperilaku baik dalam penerapan protokol pencegahan COVID-19.

Berdasarkan konidisi yang ada kurang berprilaku baik dalam penerapan pencegahan COVID-19, maka perlu dilakukan suatu upaya untuk meningkatkan kepatuhan pengujung dengan memanfaatkan situasi dan konidisi yang ada. Langkah dan upaya untuk memberikan solusi yaitu memberikan sosialisasi tentang perilaku mencegah penularan COVID-19 langkah mencuci tangan, .penggunaan masker yang tepat, menjaga jarak, etika bersin dan batuk dengan harapan dapa mengurangi resiko terpapar COVID -19 dan dapat diterapkan diluar warung kober mie setan.

Perbandingan antara pemilik, karyawan, dan pengunjung warung makan Kober Mie Setan Jember terhadap pegetahuan, Health Literacy, kepercayaan, sikap dan perilaku masyarkat terhadap prokotol kesehatan pencegahan COVID-19

Terdapat keberagaman jawaban dari responden terkait pegetahuan, Health Literacy, kepercayaan, sikap dan 
perilaku masyarkat terhadap prokotol kesehatan pencegahan COVID-19, adanya kesenjangan pengetahuan terkait COVID-19 antara pemilik, karyawan dan pengunjung. Hasil menunjukkan bahwa pengetahuan pemilik terhadap COVID-19 bagus. Sedangkan karyawan ada beberapa pengetahuannya masih kurang. Untuk variabel Health Literacy terutama pada pertanyaan informasi terkait bahaya tidak mematuhi protokol kesehatan di era new normal dari masayarakat sekitar sudah akurat atau belum. Pemilik menjawab iya, karyawan sebayak $67 \%$ menjawab tidak, pengunjung sebanyak $75 \%$ menjawab iya.

Keberagaman jawaban responden ini berkaitan dengan perbedaan akses informasi yang dilakukan oleh pemilik, karyawan dan pengunjung terhadap memastikan informasi yang di dapatkan dari satu sumber dengan sumber lainnya. Pemilik yang memiliki kualifikasi pendidikan lulusan Pascasarjana melakukan perbandingan informasi, pengunjung yang memiliki kualifikasi pendidikan terbanyak setingkat Sarjana melakukan perbandingan informasi yang di dapatkan dari sumber informasi satu dengan yang lain, namun karyawan yang memiliki kualifikasi pendidikan terbanyak lulusan SMA kurang dalam melakukan perbandingan informasi yang di dapatkan dari sumber informasi satu dengan yang lain. Demikian dapat di simpulkan bahwa keberagaman jawaban dari responden di pengaruhi oleh tingkat pendidikan antara pemilik, karyawan dan pengunjung.

Pendidikan dimaknai dengan upaya atau bentuk usaha membina kepribadian diri sendiri yang disesuaikan dengan nilai yang ada ditengah - tengah didalam masyarakat, kebudayaannya, dan lingkungannya. Usaha manusia merupakan bentuk melestarikan keberlangsungan hidupnya. Pendidikan menjadi media pembelajaran pada bagi masyarakat luas dengan tujuan agar dapat melaksanakan tindakan (praktik) tepat dan baik sehingga dapat memelihara (mengatasi) permasalahan guna melanjutkan keberlangsungan hidupnya secara sehat. Secara langsung dan atau tidak langsung tingkat seseorang atau masyarakat sadar akan pentingnya perilaku hidup sehat dipengaruhi tingkat pendidikannya yang akhirnya pendidikan tersebut akan dapat mempengaruhi kemampuan dalam upaya atau usaha melaksanakan hidup sehat [6].

Pada variabel kepercayaan terdapat keberagaman jawaban oleh responden baik pemilik, karyawan dan pengunjung yang terdapat pada pertanyaan tentang tubuh yang terpapar COVID-19 dapat sembuh dengan sendirinya. Pemilik menjawab tidak percaya, karyawan sebanyak $63 \%$ menjawab percaya, pengunjung sebanyak $60 \%$ menjawab percaya. Keberagaman jawaban responden ini dapat terjadi karena tingkat pendidikan responden yang berbeda. Penilik memilki kualifikasi pendidikan lulusan pascasarjana jurusan kesehatan, karyawan memilki kualifikasi pendidikan lulusan SMA sebanyak 90\%, sedangkan pengunjung memiliki kualifikasi pendidikan SMA sebanyak 46,7\%. Pendidikan berpengaruh terhadap pengetahuan dan pengetahuan berpengaruh terhadap perilaku seseorang.
Sesuai dengan pernyataan menyatakan bahwa pengetahuan berhubungan dengan perilaku seseorang dalam mencegah COVID-19 [1].

Penelitian Alrubaiee and Al-qalah juga menyebutkan bahwa pendidikan berhubungan dengan pengetahuan seseorang, kesimpulan yang dapat ditarik dengan peningkatan tingkat pendidikan individu (seseorang) maka juga dapat diikuti dnegan peningkatan pengetahuan orang itu sendiri dan akhrinya berdampak pada perilakunya [1]. Keberagaman lain terkait jawaban pada soal terpaparnya COVID-19 pada tubuh manusia merupakan takdir yang maha kuasa yang tidak diawali dengan usaha pencegahan. Hasil jawaban bahwa pemilik menjawab tidak percaya manusia langsung tertular, karyawan sebanyak 93\% menjawab percaya bahwa tertular merupakan takdir tanpa ada usaha, dan begitupun pengunjung sebanyak 52\% menjawab percaya.

Keragaman jawaban ini bisa disebabkan karena kurangnya akses informasi karyawan dan pengunjung terhadap COVID-19 sehingga menyebabkan pengetahuannya juga beragam dan berdampak pada pencegahan COVID-19 oleh karyawan dan pengunjung yang masih kurang disiplin dilaksankan. Pada variabel sikap terdapat perbedaan sikap yang sangat jauh antara pemilik, karyawan dan pengunjung mengenai protocol kesehatan untuk mencegah penyebaran virus COVID-19 di rumah makan Kober Mie Setan Kabupaten Jember.

Sikap pemilik terhadap protokol pencegahan COVDI-19 selama pandemi COVID-19 sudah cukup baik, hal ini dikarenakan pemilik rumah makan Kober Mie Setan merupakan lulusan strata 2 sehingga cara berfikir jauh lebih mampuni (visioner) dalam penerapan pencegahan COVID19. Kondisi dengan tingkat pendidikan seseorang dapat mengubah pola pikir pemilik dan langsung menerapakan pencegahan COVID-19 di rumah makan Kober Mie Setan. Langkah yang ditetpakan bagi pengunjung harus melakukan pengukuran suhu dan meminta karyawan mengigatkan bahwa pengujung harus melakukan 7 langkah cuci tangan menggunakan sabun atau handsanitizer dan menjaga jarak. Perihal langkah tersebut dilakukan oleh pemilik kepada pengujung dan karyawan karena kurangnya kesadaran dari diri para pengunjung untuk menerapkan protokol pencegahan COVID-19 selama di warung kober mie setan.

Faktor budaya juga mempengaruhi sikap dan perilaku seseorang untuk selalu menjaga kesehatannya. Pada variabel perilaku terdapat perbedaan perilaku antara pemilik, karyawan dan pengunjung hal ini karena bahwa karakteristik yang berbeda seperti jenis kelamis, umur dan tingkat pendidikan. Pemilik warung mempunyai perilaku yang baik terhadap pencegahan COVID-19 sesuai dengan SOP protokol kesehatan. Perihal tersebut didukung dengan pemilik warung yang merupakan seorang perempuan berusia $>21$ tahun berpendidikan strata 2 ilmu kesehatan. Menurut Aubee dalam Kurniasari, perempuan mmempunya perbedaan dengan laki dalam hal rasa kebertanggungjawaban yang lebih dalam kesejahateraan lingkuangan dan orang diseklilingknya, kecenderungna dengan sifat yang openuh kasih sayang, dan sering 
menerapkan sifat kelemha lembutannya. Berdasarkan kondisi seorang perempuan yang telah disebutkan terseut akan meningkatkan seorang perempuan lebih cenderung patuh akan kebijkan yang ditetapkan.

Pada variabel prilaku karywan sendiri sudah baik dalam mematuhi protokol kesehatan meskipun ada beberapa yang perilakunya tidak baik dalam mematuhi protokol kesehatan seperti hanya terkadang dalam menggunakan face shield saat memasuki warung. Dilihat darii sisi pengunjung didapatkan bahwa pengunjung sudah menunjukkan perilaku baik meskipun ada beberapa yang tidak berperilaku baik hal ini dikarenakan bahwa perbedaan karakteristik pada pengunjung yaitu mayoritas adalah lakilaki dan ada yang berpendidikan SMP.

Seseorang yang memiliki pola pikir yang baik dapat mempengaruhi sikap seseorang untuk melalukan tindakantindakan yang baik termasuk menjaga kesehatan diri selama pandemic COVID-19. Sikap karyawan Kober Mie Setan usdah cukup baik secara keseluruhan, hanya saja beberapa dari mereka enggan untuk mencari informasi mengenai perkembangan COVID-19. Perihal tersebut dikarenakan dari mereka lebih menghindari rasa takut berlebihan yang akan ditimbulkan setelah mengetahui perkembahan penyakit COVID-19. Mereka juga memiliki pola pikir seperti untuk apa kita harus takut dengan COVID, hidup mati manusia ditangan Tuhan. Terdapat juga beberapa dari mereka memang tidak ada waktu untuk mencari informasi mengenai perkembangan COVID-19 dan lebih memilih istirahat dikarenakan jadwal jaga karyawan dengan 2 shift yaitu pagi dari pukul 10.00 s.d. 18.00 WIB dan sore dari pukul 14.00 s.d. 22.00. WIB. Pada poitn sikap oleh pengunjung yang terkadang masih acuh tidak acuh terhadap penerapan selalu penggunaan masker secara tepat.

\section{Kesimpulan}

Warung Kober Mie Setan telah memenuhi beberapa standar untuk menjadi "Warung Tangguh COVID-19" karena Warung Kober Mie Setan telah melakukan penerapan pencegahan COVID-19 di warung makan berdasarkan buku panduan pelaksanaan pelayanan di retoran atau rumah makan selema pandemi COVID-19. Pada proses keberlangsungan penerapan protokol pencehan COVID-19 terdapat beberapa point tambahan yang perlu dilakukan dalam mewujudkan Warung Kober Mie Setan sebagai warung tangguh COVDI-19, oleh karena itu kami melakukan sosialisasi dan edukasi terhadap pemilik, karyawan mengenai standar palyanan restoran dan rumah makan selama pandemi COVID-19. Hasil jawaban berdasarkan instrumen yang dibagikan juga terdapat keberagaman jawaban dari responden terkait pertanyaan antara pegetahuan, Health Literacy, kepercayaan, sikap dan perilaku terhadap prokotol kesehatan pencegahan COVID19 di warung makan Kober Mie Setan Jember.

\section{Ucapan Terimakasih}

Penysusunan artikel terkait pencegahn COVID-19 tentunya membutuhakan bimbingan dan arahan dari berbagai pihak. Kami dari tim penulis menyampaikan ucapan terima kasih kepada Direktur Pascasarjana bapak Prof. Dr. Ir. Rudi Wibowo, MS., Ketua Program Studi Magister Ilmu Kesehatan Masyarakat bapak Dr. Isa Ma'rufi, S.KM., M. Kes., dan dosen pembimbing Dr. Ir. Sugeng Winarso,.M.Si yang memberikan banyak arahan sehingga artikel ini dapat tersusun dengan baik serta tim pelaksana dan warung Kober Mie Setan yang telah bersedia menjadi tempat pelaksanaan kegiatan.

\section{Acuan Referensi}

1. Alrubaiee, G. G., \& Al-qalah, T. A. H. (n.d.). preventive behaviors towards COVID-19 among health care providers in Yemen: an online cross- sectional survey. 1-20.

2. Almi.(2020).https://almi.or.id/2020/06/05/analisispenyebabmasyarakat-tidak-patuhpada-protokol-COVID-19/diakses 28 November 2020.

3. Audri Okta AWD (2019) Hubungan Pengetahuan dan Sikap Terhadap

4. Hanik, C. 2020. Ancaman Berita Bohong di Tengah Pandemi COVID-19. VOX POPULI Vol. 3, No. 1. Diakses diakses 19 Oktober $2020 \quad$ http://journal.uinlauddin.ac.id/index.php/voxpopuli/article/view/14395/8604

5. Fatimah Nurliza, Lala Amelinda F, Trinadi Maulana P. 2020. Upaya Birokrasi Pemerintah dalam Mensosialisasikan COVID-19 di Lingkungan Masyarakat. Jurnal Ilmiah Ilmu Administrasi Vol 3 , No. 1. Diakses 17-10-2020

6. Santosa, K.S,. 2012. Faktor-faktor yang berhubungan dengan tingkat kemelakan kesehatan pasien di Klinik Dokter Keluarga Fakultas Kedokteran Universitas Indonesia Kiara, DKI Jakarta.

7. Kemenkes RI. Keputusan Menteri Kesehatan Nomor HK.01.07/Menkes/382/2020 tentang Protokol Kesehatan bagi Masyarakat di Tempat dan Fasilitas Umum dalam Rangka Pencegahan. Jakarta: Kemenkes RI

8. Mujayapura, Muhammad Retsa Rizaldi. 2020. COVID-19, Konspirasi, dan Ketahanan Teknososial. Lipi- Research Center for Society and Culture-Indonesian Institute of Science. Diakses diakses 17 Oktober 2020 https://pmb.lipi.go.id/COVID-19konspirasi-dan-ketahanan-teknososial/

9. Satgas COVID-19 Pemkab Jember. 2020. Data pantauan dan sebaran COVID-19 di Kabupaten Jember. Jember: Pemkab Jember.

10. Plohl, N., and Musil, B. 2020. Modeling compliance with COVID-19 prevention guidelines: The critical role of trust in science Modeling compliance with COVID-19 prevention guidelines: The critical role of trust in science Nejc Plohl a * and Bojan Musil a a Department of Psychology , U. Psychology, Health \& Medicine, 00(April), 1-12. Received https://doi.org/10.31234/osf.io/6a2cx.

11. Presiden RI. 2020. Keputusan Presiden Nomor 11 Tahun 2020 telah menetapkan Kedaruratan Kesehatan Masyarakat COVID19. Jakarta: Presedien RI

12. Presiden RI. 2020. Keputusan Presiden Nomor 12 Tahun 2020 tentang Penetapan Bencana Nonalam, bahwa Penyebaran COVID-19. Jakarta Presiden RI.

13. Ta'adi, Setyorini, E., and Amalya, R,. 2019. Faktor yang Berhubungan dengan Kepatuhan Cuci Tangan 6 Langkah Momen Pertama pada Keluarga Pasien di Ruang Anak. Jurnal Ners dan Kebidanan. Vol 6. No 2. Agustus 2019. hlm. 203-210: DOI: 10.26699/jnk.v6i2.ART.p203-210

14. World Health Organization. 2020. COVID-19 and food safety: 
guidance for food business. Dipetik 27 April 2020, dari https://www.who.int/emergencies/diseases/ novel-coronavirus2019/technical-guidance.

15. World Meters. 2020. Info Corona Virus. https://www.worldometers.info/coronavirus/. [diakses pada tanggal 25 Oktober 2020] 17 